\title{
Being an environmentalist among Catholics... The School of Integral Ecology Leaders and Other Initiatives of the St. Francis of Assisi Environmental Movement (REFA)
}

\author{
Emilia Ślimko, Stanisław Jaromi* \\ St. Francis of Assisi Environmental Movement (REFA) \\ Żółkiewskiego 14, 31-539 Krakow, Poland \\ * sjaromi@franciszkanie.pl• ORCID 0000-0003-0719-6184
}

\section{Summary}

This study provides a summary description of the abundant activities of the St. Francis of Assisi Environmental Movement (REFA), which emerged over 30 years ago in the environment of Polish Franciscans and which ever since has been propagating the idea of engaging Christians in environmental protection issues. REFA's motto is "Catholics among ecologists, environmentalists among Catholics." In its activity, REFA has undertaken many different pro-environmental initiatives and implemented many ecological projects, part of which are presented in this study.

\section{Keywords}

St. Francis of Assisi Environmental Movement, REFA, Christian ecology, integral ecology, ecological crisis

\section{Introduction}

Since its very beginning in the 1980s, the St. Francis of Assisi Environmental Movement (REFA) has been involved in promoting the principles of Christian ecology as well as the attitude of respect for creation in accordance with the Franciscan spirituality. We would like to become the voice of ecologists in the structures of the Catholic Church and the voice of Christians among ecologists. We are committed to protecting the natural environment at local and global levels and, therefore, we are striving to implement educational goals in specific projects, publications, events and social media, encouraging social involvement and jointly developing new opportunities for various initiatives.

\section{Shaping the message of REFA's Franciscan ecology}

Referring to the genesis of the issue, it is necessary to mention the situation in Poland in the eighties and, in particular, the huge damage to the natural environment done as a consequence of the economic activity at the time of the People's Republic of Poland based on the reckless draining of natural resources and neglect of any standards. It was then, when both civic and Catholic circles began to be actively involved in various pro-environmental 
initiatives. The significance of the Catholic Church's involvement was emphasized by the Pastoral Letter of Polish Bishops on the subject of environmental protection of 05.05.1989. Franciscans, following Pope John Paul II's proclamation of St. Francis of Assisi patron of ecologists in 1979, felt particularly obliged to undertake action in this respect. Consequently, a number of ecological initiatives primarily related to the Franciscan spirituality were launched, for example, in Krakow, Katowice, Wrocław, Legnica, Poznań, Łódź, Gdańsk, Warsaw, Lublin and Jasło. Moreover, a number of Catholic ecological education centres were founded, among others, in Krakow, Lublin, Zawoja in the Beskids and Wisełka in Pomerania. Among those, REFA is probably the only one still continuing its activity. As regards tourist and other initiatives promoting all types of leisure activities in nature, the situation seems to be slightly better (Jaromi 2011).

The St. Francis of Assisi Environmental Movement (REFA) was established in 1981 in Krakow as a direct reaction of the Franciscans to announcing on November 29, 1979 St. Francis of Assisi patron of environmentalists by Pope John Paul II. Another factor was associated with the socio-political atmosphere of Poland at that time, which led to revealing the real ecological threat in our country. The desire for ecological action thus appeared in a concrete way of implementing Franciscanism in the contemporary situation.

As part of a very diverse and multi-faceted social ecological movement in Poland, according to the sociological criterion of style of action, we can be included among groups established with the aim to conduct long-term activities, addressing a variety of ecological problems and aiming at implementing fundamental social changes. We have always highlighted the importance of the so-called "small path" which lead from shaping individual pro-ecological attitudes to specific actions. This attitude was expressed by the slogan "Ecology begins in the heart" as well as by the Movement's logo having in its centre a heart carried by a spiritual son of St. Francis, who is permanently united with the world of creatures through a symbolic green leaf.

In the pastoral programme of the Church in Poland for 2008/2009 by the Commission for Christian Ministry of the Polish Bishop's Conference, encouraged a broader introduction to catechetical, preacher, retreat and other pastoral ministry of broadly understood care for life, St. Francis of Assisi Environmental Movement was shown as a modern and evangelical example of concern for the life of nature. "REFA combines the spiritual richness of Franciscan ecology (from the time of the Saint, through the natural traditions of Franciscans, to current ecological Franciscan thought), with contemporary Christian science of the natural environment, emphasizing in particular the teaching of the Catholic Church on the natural environment, ecology and nature conservation. Everything together is based on the Christian concept of the world and man created by God, redeemed by Christ and sanctified by the Holy Spirit” (Brusiło 2008: 342).

The authors grasps the genesis of the Franciscan commitment to ecology as follows: "St. Francis of Assisi Environmental Movement was created as a response to contemporary ecological threats, which is why the association addresses the signs of time and the need to protect nature both on a regional and national scale, together with other pro-ecological groups and associations that rest their activities on similar assumptions. In this context, the Movement seeks to act not only towards, for example, pro-ecological legislative changes in the whole society but also towards shaping human thinking and conscience. REFA's actions-by definition-are part of the global nature protection programme and they are addressing the biblical core of the human person, i.e. the human heart in which the effects of global ecological threats are experienced and in which the specific human response to these threats is shaped in 
the immediate environment." Brusiło 2008: 343).

After discussing numerous specific activities of REFA and its circles, the following is summarized: "Undoubtedly, the ideas of REFA are not a closed area for new inspirations and activities of a religious, social and ecological nature. The long-term projects and actions that have been undertaken throughout more than 25 years of REFA's activity have shown the right direction of Christian care for nature. The Movement's activity not only has a future but it is of great importance from the point of view of the socio-ecological involvement of the Church and from the point of view of the spiritual strengthening of ecological goals and aspirations of naturalists concentrated in pro-ecological associations and secular organizations. The common denominator of these ideas is the Franciscan opening to nature and spiritual dialogue with all creation to which St. Francis referred to as his brothers and sisters. It is only Christian and Franciscan theology of creation, but also ethics, protection and care for the natural environment which are in the centre of human interest and the still relevant thought of the Saint of Assisi can become a means of getting to know the natural world and saving the endangered environment" (Brusiło 2008: 345).

It is worth mentioning also that, according to the statute, REFA's ideas are shaped by: 1) Francis's vision of solidarity and brotherhood with all creatures, which is well expressed in the contemporary decalogue of St. Francis, based on his writings and early Franciscan sources; 2) Fascination with the beauty of nature, but also due to the "ecological shock" caused by learning about the magnitude of the ecological crisis in Poland and the world, personal contact with the effects of destruction of nature and human health, and thorough knowledge of nature, ecology, philosophy and theology, and 3) Social teaching of the Church and the thought of John Paul II, because we understand the goal of the Movement as "active participation in building a civilization of love based on the primacy of a person before a thing, ethics before technology, a strive to "be more" before a strive to "have more", mercy before justice, through fraternal treatment of man and nature" (REFA Statute).

Throughout its long history, REFA has implemented many projects, including:

- The Franciscan Ecological Education Project, which comprised preparation of numerous educational, liturgical and preaching materials, popularizing the Christian approach to ecology, social teaching of the Church and Franciscan spirituality.

- Ecological Workshops REFA organized in the years 1994-2009 whose participants were invited to selected national or landscape parks;

- The Map of Christian Ecological Initiatives, where we collected data on ecological initiatives undertaken in Poland and drawing their inspirations from the Christian thought,

- The Gardens of St. Francis, promoting the preservation of natural or semi-natural ecosystems through social protection of nature refuges, referring to the idea expressed by the Ecologists' Patron, to leave at the monasteries "an uncultivated border so that the herb greenery and the beauty of flowers praised the Father of all beautiful things in their time" (Thomas of Celano 1981: 167). Such places, apart from their natural and teaching value, are supposed to serve the social goals of the local community and become places where people might rest, contemplate and spend free time surrounded by nature. According to our assumptions, the Gardener of St. Francis is a special type of architect who not only designs and creates space, but also cultivates life. This also applies to human ecology, i.e. those values that serve our regeneration (physical and spiritual) and rest. 
Therefore, three aspects harmonize here: natural (environmental), social (community) and religious (spiritual). The statue of St. Francis placed in the garden is to indicate that inspiration and help should be sought in this Saint and in his spirituality (Jaromi 2010a).

- The Brehov project - international meetings of the young from Franciscan ministries of Eastern European countries organized four times in the years 2000-2003 in the Slovak Brehov, Hungarian Eger and Vilnius, in which we included ecological education;

- The Green Notebook REFA - our newsletter published in the years 1988-2011, providing answers to many questions about Christian ecology, reflection on the place of our Saint $\mathrm{Pa}$ tron in social activity and practical suggestions for use in ecological education (Jaromi 2010b).

- The project "Fill the Earth and love it!", whose goal was to create an integral ecological education programme taking into account the ethics in line with the idea that ecology begins with the change of the heart, mentality and sense of responsibility for the world. The slogan "Fill the Earth and love it!" is a response to the accusations of excessive exploitation of the world due to the implementation of the biblical command.

- The centre for saving and promoting ecological energy sources in the Church "Ethics \& Energy", where (in 2011-2015) we co-created an expert group supporting the implementation of sustainable and balanced development of local parish and monastery communities, ecological lifestyle and rational energy management. In cooperation with professional organizations and companies, we supported the idea of conducting an ecological audit of church buildings and energy saving projects, and we promoted alternative energy sources in church and parish buildings, as well as ecological forms of transport.

REFA's activities for the Polish Council of Catholic Movements were of special importance, especially during their subsequent congresses. The issue of ecology in the apostolic ministry was particularly strongly accentuated within the framework of the Third National Congress of Catholic Movements and Associations, which took place in 2005-2007. It was planned as an in-depth, systematic and modern reflection on new challenges at the beginning of the new millennium. The main method of work was a monthly thematic congresses devoted to, among others family, ecology, culture, mysticism, globalization, youth and the media. In total, it included over 350 papers, lectures and testimonies as well as panel discussions attended by over three thousand people. Others could share their experience of involvement in Church activities through the Congress website (Web-o1). The St. Francis of Assisi Environmental Movement was responsible for preparing and coordinating the area of issues related to Christian involvement in ecology. REFA members prepared a website with educational materials and on November 19, 2005, they organized a special session "Christians and Ecology" in Warsaw, followed up by the issuing of a folder popularising the subject and scope of REFA's activities, as well as a publication entitled Christians and ecology (Web-o2). Extensive material summarizing all activities was published on the congress website and in a special book (Jaromi 2007). Although it was shown that the problem of environmental protection is important in the life of Christians, the Church and society, it turned out that general knowledge and interest in the ecological issues is rather superficial. However, we managed to awaken the ecological sensitivity of congress participants and point out that environmental protection is, in fact, a matter of protecting life and responsibility for it.

According to REFA, several important proposals emerged from congressional 
discussions, such as 1) Improving the effectiveness of teaching Christian values on environmental issues by preparing appropriate materials for priests, catechists, teachers and all concerned; 2) Creating a central centre of Christian ecological education; 3 ) Including in the liturgy prayers for the purpose of respect for the Work of God, especially for water, land and natural resources; 4) Organizing occasional ecological days included in the programmes of parishes, communities, holidays or school trips, whose purpose, apart from an interesting use of time and place or acquiring new knowledge, would be to shape an attitude of respect for the world of nature as God's creation and to create a sense of responsibility for nature; 5) Promoting the person and spirituality of the Ecologist Patron, St. Francis of Assisi, as a "benchmark" among the various ecological education proposals; 6) Encouraging Catholics to reflect on their lifestyles, especially with regard to quality of life, health, leisure activities, needs, consumption attitudes, production of excessive amounts of waste, etc.; 7) Emphasizing educational activities with children to shape their sensitivity to the beauty, beauty of the world and wisdom of nature (Jaromi 2007: 118ff).

Similarly, the service of ecology was undertaken as part of the 4th National Congress of Catholic Movements and Associations, held in 2010-11. This time, attempts were made to provide answers to the questions: How to develop proecological attitudes and a Christian approach to consumption? How should Christians respond to new challenges? Should we read current ecological disasters as the "signs of the times"? Those questions were addressed at the conference "Christians in the Face of Contemporary Challenges of Ecology and Consumption" organized on 22.05.2010 in Warsaw. Various ecological topics, among others issues of biodiversity and climate change, GMOs in agriculture and responsibility for ecological disasters, were presented from a Christian perspective.
"All this prompts us to take even greater care for our world and recognize its biodiversity as a gift of the Creator and a value in itself. The failure of climate negotiations and the invasion of GMOs in agriculture, however, testify to the victory of actions aimed at profit and egoism of the richest. The voice of Christians must therefore call for greater responsibility for the shape of our civilization, for creation and for the needs of the poorest." (REFA Archive).

The brief presentation of the congressional works and the accompanying discussions resulted in the formulation of the most important conclusions and guidelines that defined the directions and areas of the Church's involvement in the ecological issue. That extensive material allowed to formulate the following inspirations and indications:

- lifestyle as a testimony of Christians for today - a style emphasizing the value and wealth of all life, moderation and responsibility for God's work, not chasing consumption, satisfying material needs and thus greater exploitation of natural goods;

- deepening knowledge of the Church's social teaching on environmental issues;

- propagating a full spectrum of ecological issues, covering both genuine human needs and care for the entire created world;

- raising the ecological awareness of society and treating environmental protection as a special duty of every Christian rather than as an obstacle in satisfying one's own needs;

- care for the so-called small-scale household ecology, i.e. care for clean air, water, soil as well as for peace and a good neighbourly atmosphere; care for economic use of food, water, energy and all natural resources;

- developing sensitivity to the beauty of creation as a way of God's affirmation-prayer through contemplation of nature; 
- joining ecological education projects implemented by the St. Francis of Assisi Environmental Movement.

It is worth recalling all the activities undertaken many years before the publication of encyclical Laudato si', highlighting the great effort of REFA activists engaged in promoting ecological education within the Church. This period of REFA's activity sketched against the background of the entire Polish ecological movement was presented in the 2014 publication Przez ekologię do wolności (Through Ecology to Freedom) (Jaromi 2014).

\section{REFA School of Integral Ecology Leaders}

Since June 18, 2015, i.e. the date of Laudato $s i$ ' publication, we have been actively involved in the promotion of the encyclical's message, among others through our website "Święto Stworzenia" (Season of Creation) (Web-03), in social media (Web-o4; Web05 ), by organizing and taking part in various events and initiatives, as well as through our presence in traditional and social media. One of the latest outcomes of REFA's commitment to promoting the message of the "green" encyclical is the School of Integral Ecology Leaders (Web-o6). Having spoken in REFA for years about the issues of Christian ecology, we have realised that a real change in the world requires each of us to take responsibility for the quality of our lives and the surrounding natural environment. The world needs leaders who, by their commitment, will inspire others to act. The essence of our proposal is to recognize that the Earth is a common good of all humanity, and we, as Christians, are particularly responsible for its protection. Integral ecology shows how to reorganize spiritual, social and economic life to overcome the escalating socio-ecological crisis. Thanks to the School of Leaders, we are creating a network of committed Christians for whom protection of the entire creation and the ecology of everyday life constitute the highest priority. We also see this project as a direct response to the call of Pope Francis who on July 6, 2018, at a special conference in the Vatican entitled "Saving our common home and the future life on Earth", spoke about the need to undertake an individual mission to save our planet as a common home for all humanity. The conference, which gathered over 300 environmental activists from around the world, was also attended by REFA representatives, Father Stanisław Jaromi and Kasper Jakubowski. St. Francis of Assisi Environmental Movement was among the 12 Catholic ecological initiatives that presented their activities during the conference.

As part of the School of Leaders activities in the period from June 2018 to May 2019, we carried out workshops and meetings, which were attended by over 30 people from all over Poland, who wanted to initiate action in local communities and parishes, looking for inspiration, exchange of experience and knowledge in the field of Christian perspective on ecology. We addressed a variety of topics oscillating around the following questions: ways of translating the Christian attitude to creation into practical action; the character of the integral ecology model and the lifestyles implementing it; the ways we, as Christians, can get involved in the ecological and social challenges of the modern world; who is the leader of an integral ecology. Particularly noteworthy are the workshops we organized in 2018 in Katowice during the United Nations Conference on Climate Change (COP24). Together, we discussed the ways in which REFA members could join in climate protection and education of local communities. At that time, we also prepared a letter of Christian ecologists to the participants of the Climate Summit. The signatories of the letter called for "ecological conversion" so that the common good would triumph in UN negotiations and that the right decisions would be made regarding the future of life on Earth: "We moreover ask Poles and all inhabitants of our planet to become involved in the protection of the Earth's climate in the spirit of responsibility 
and solidarity - and, in this way, to protect the lives and health of people on this Earth. We are convinced that Christians - and all people of good will - can answer the call of John Paul II and Francis to 'ecological conversion"' (Web-o7).

Who is the modern leader of an integral ecology? We came to the conclusion that what is of importance in this respect is personal involvement and inspiration of others. This is how we formulated our "definition" of the integral ecology leader, i.e. a person who takes to heart Christian values in ecology and who wants to cooperate with others to change the local environment. We also assumed that the key issue is to take responsibility for the shape of reality that we are co-creating. We had more than one opportunity to consider together the qualities characterizing the leader. To become a leader, it is necessary to authentically implement in our daily lives the professed principles. It takes courage and enthusiasm to inspire others to action as well as open communication which relies not only on saying politically incorrect things or calling for a change of the lifestyle. Open communication assumes personal concern for the proper ways of communicating with others, the people we work with and function on a daily basis. It also implies adopting a non-exclusive attitude, work towards unity and agreement, a constructive approach to conflict resolution, searching for things that we have in common and building "bridges" (Web-o8). It is also important to develop mindfulness and a specific attitude of the heart: "experiencing everything with cheerful concentration" [Francis 2015: No. 226], which is realized in attentive being, kindness to oneself and others, creating space for cooperation and action for the common good (Web-o9).

The School of Integral Ecology Leaders is a project meant to inspire, disseminate knowledge and encourage personal involvement. It is an open project that can be joined at any time. To this end, we have prepared an online course for self-education in the e-learning mode in the field of integral ecology, easily accessible to all interested (Web-o6). The course consists of the following parts: 1). Large-scale ecology covers the most important environmental problems from a global point of view; 2). Small-scale ecology - presents ways to care for our immediate natural environment on a daily basis; 3 ). Ecological teaching of the Church - presents the Church's teaching on the protection of creation, including its moral aspects; 4 ). The leader of integral ecology - contains tips on how to become a leader in integral ecology.

One of the outcomes of the meetings organized within the School of Leaders is the Laudato si' Communities project, whose foundations were formulated by the chairman of REFA, Father Stanisław Jaromi. The main assumptions of that community are the choice of: peace, not war, mutual respect, not aggression and persecution, common good, not self-centeredness, healthy living, not poisoning water, air, food and ourselves, care for nature and not its exploitation, ethical behaviour towards animals, not mindless cruelty and attentive listening to ecological and social challenges of modern times. The leader should be responsible for such a community and, together with it, report to the local priest or superior of the monastery. REFA should provide substantive and spiritual care of the community. It is also important to cooperate with various religious, social, ecological and charitable organizations, e.g. Caritas, KSM and the World Catholic Movement for the Environment. Communities, although autonomous, can create a network of cooperation among themselves, inspiring each other and implementing joint projects. They can draw on the rich heritage of Christian spirituality with particular emphasis on the Franciscan and ecumenical traditions and the message of the encyclical Laudato si'.

The effects of the School of Leaders project were presented in May 2019 in Warsaw at the 12 th conference from the cycle 
"Humanistic Ecology", entitled "The Church and the Ecological Crisis. On the 3oth Anniversary of the Polish Bishops' Pastoral Letter on Environmental Protection". It was organized by the Institute of Ecology and Bioethics of UKSW, St. Francis of Assisi Environmental Movement and the World Catholic Movement for the Environment. Its purpose was to show the Church's commitment to recognize and overcome the environmental crisis. Ecological initiatives of the Catholic Church in Poland were presented at the conference, both by official representatives of the Church and of Catholic movements and organizations. On behalf of REFA, Father Jaromi presented the paper "Dialogical and Mediatory Potential of Integral Ecology”, Emilia Ślimko presented the project of the School of Integral Ecology Leaders and Weronika Felcis made a presentation on local ecological activities in Estonian parishes and communities. At the end of the conference, the participants heard and signed an "Appeal of Christians and People of Good Will to Respect the Creation", in which they asked "Christian sisters and brothers and all people of good will to take individual and joint actions aimed at protecting the climate, saving natural resources, not wasting food or littering, responsible consumption, care for greenery around our homes, respect for animals, preferences of public transport and other forms of reducing pollution and the negative human impact on the environment, as well as care for the most deprived, which embrace not only people and other beings living today, but also future inhabitants of the Earth" (Web-10).

\section{Promotion of the Laudato si' message and other REFA activities}

The Polish presentation of the ecological encyclical of the Holy Father Francis Laudato $s i$ ' took place alongside that conducted in the Vatican on June 18, 2015 at the secretariat of the Polish Bishop's Conference in Warsaw. A week later, on June 25 , the encyclical was presented in Krakow in the portrait hall of the City Hall. In both meetings, the content of the document was discussed by Father Stanisław Jaromi, head of REFA. And since then we have been systematically publishing interviews, comments and polemics regarding the teaching of the Church contained in the encyclical. The biggest activity on this topic was the conference "Church and Science in the Face of Ecological Challenges", where the Jesuits and Franciscans jointly reflected on this important document of Pope Francis, a Jesuit with a Franciscan heart, and presented its topics in the context of the Church's teaching and the data of modern science. Scientists from various academic, clerical and secular centres were invited to participate in this task whose outcome was the first academic monograph on the message of Laudato si' published in 2016 (Poznański, Jaromi 2016).

Among the numerous activities, it is worth noting that since 2015, REFA has been organizing the Season of Creation (Web-11) in Poland. This is an international initiative that accompanies the World Day of Prayer for the Care of Creation and is held in Poland from September 15 to October 15. At this time, there are special services and prayer meetings to protect the created world, for the victims of recent natural disasters and for the project of an integral ecology presented in the encyclical Laudato si'. The eco-encyclical accompanied the celebration of St. Francis' day, animal blessings and family walks around the urban uncultivated areas, where we encouraged to waste time with children and joyfully explore unusual places in the area. The honorary patron of the action is the Primate of Poland, Archbishop Wojciech Polak (Web-12).

One of the major international events in which we participated as REFA was the World Youth Day in Krakow in 2016. We coordinated the establishment and organization of the international ecological village of Laudato si' (Web-13) at the Youth Festival in a city park together with ecologists from Australia, Philippines, Brazil, 
USA, Kenya, gathered in various Catholic ecological organizations.

Seeing that among many initiatives on the religious map of Poland, there was no meeting place for Catholics involved in ecology and the protection of creation, we created a portal of Christian ecologists called the Festival of Creation. The portal presents a Christian voice in the broadly understood ecological issues and its main thematic areas include: the study and popularization of the Church's teaching on ecological topics, Christian ecological education, shaping the proper image of an ecologist-a Catholic, popularizing the idea of the Season of Creation and a lifestyle respecting social and natural limitations, care for reducing energy consumption in the Church, organic farming and food sovereignty. Our motto is "Many small people in many small towns who do many small things can change the face of the world..." The portal that started on the Pentecost in 2012 has become an important place of debate and information on Christian ecology.

This initiative was soon noticed and its creator and main editor, Father Stanisław Jaromi, received prestigious awards. In recognition of his work in the ecological movement on October 17, 2015 in the auditorium of the Institute of Biology of the University of Natural Sciences and Humanities in Siedlce he received the "Polish Forget-me-Not Medal" established by natural scientists. In addition to the Medal, the laureate received a commemorative diploma with a dedication: "For those who enthusiastically work, clean, study, plant trees, encourage others, can admire, despite bad weather, a leaf trembling in the wind, the smell of nature. For those who never cease in their efforts, and give their heart to Polish Nature".

In the Warsaw site of the episcopate on February 25, 2016, Father Stanisław received the award of Bishop Roman Andrzejewski for 2015 for long and consequent work for ecological education, managing the REFA association, promoting the teaching of the encyclical Laudato si' and support for traditional and organic farmers.

In turn, on May 31, 2017 he was awarded the title of the Man of the Year of Polish Ecology (Web-14). The award ceremony took place in Warsaw during the inauguration of the central celebrations of World Earth Day in Poland. Father Jaromi was awarded in recognition of his longstanding ecological commitment and effort to promote the encyclical Laudato si' and popularise Christian ecology in Poland.

In 2017, we implemented in Krakow an educational project "Oswajamy przyrodę miasta i okolic" ("Becoming Familiar with the Nature of the City and the Surrounding Area"), bringing closer valuable natural areas and urban wasteland as a meeting place for residents of the city with ecology (Web15). In 2018, we were invited to participate in the 11th Gniezno Congress and Camp for Climate, where our team promoted the message of the encyclical Laudato si' and the School of Integral Ecology Leaders. It is also worth mentioning the 2018 publication of a book by Father Jaromi Idea franciszkańska. Wielkie problemy wspótczesności i nasze mate odpowiedzi (The Franciscan Idea. Great Problems of the Present Day and Our Small Replies), in which the author puts forward the thesis that Franciscan ideas are highly topical in the era of contemporary challenges and that they can provide many tips on how to deal with the socio-ecological crisis (Web-16).

It can be contended that during the 35 years of REFA's activity, the perspective of Christian values in ecology has been introduced to public debate in Poland. The uniqueness of this perspective on ecology consists in the recognition of John Paul II's words that "man's major wealth is man himself together with the Earth" (John Paul II 1991: No. 32), and it is particularly important to emphasize this thought in dealing with the global socio-ecological crisis. We cooperate with Polish and foreign organizations, and REFA is a member of national and international networks 
such as: Polish-wide Council of Catholic Movements; More than Energy; Franciscans International; Franciscans for Justice, Peace and the Protection of Creation; Terra Mater; Global Catholic Climate Movement, Commission for Civic Dialogue (KDO) for the Environment at the City of Krakow.

\section{Conclusion}

Our deliberations and considerations give rise to the reflections:

- we need stronger cooperation and greater involvement of Catholic communities in Poland in initiating ecological activities and building ecological awareness of Polish society;

- ecological teaching of the Church may provide a response for Catholics (and not only) to local and global challenges;

- we need to document good practices, support and inspire each other as a network of people, local leaders united by a shared idea of integral ecology;

- everyone can engage according to their talents and abilities so that these actions result from personal calling and authenticity.

Aware of the socio-environmental challenges we face today, we hope that our actions will contribute to real changes, and integral ecology will become one of the most important perspectives on the modern world.

A model for the implementation of the papal project of integral ecology, adopted on November 26, 2017 during the REFA formation meeting in Radomsko may well sum up the present paper:

- we protect nature-we support projects aimed at protecting Polish nature and the endangered species as well as activities aimed at banning bird hunting; we are developing the project of the Gardens of St. Francis; we teach others on nature walks to counteract the syndrome of deficiency in contact with nature;
- we care for the environment-we are involved in activities for healthy environment, we participate in anti-smog, climate protection and renewable energy campaigns; we cooperate with organic farmers and pro-life activists, we promote ethical, sustainable thinking about transport, the ecology of the city and human settlements;

- we serve people-we develop human ecology, bioethics, eco-ethics and promote Christian social reflection, we engage in activities for fair-trade and protection of human life from conception to death, we implement eco-education for families with small children; we love God the Father-we promote the Season for Creation, a world day of prayers for the protection of the created world, the eighth works of mercy and the whole spiritual project of the encyclical Laudato si', we invite you to pray through the intercession of the patron of ecologists St. Francis of Assisi for the victims of ecological and social catastrophes.

\section{Bibliography}

Brusiło J., 2008, Ruch Ekologiczny św. Franciszka $z$ Asyżu (REFA) jako nowoczesny $i$ ewangeliczny przyktad troski o życie przyrody (St. Francis of Assisi Environmental Movement (REFA)as a Modern and Evangelical Example of Concern for the Life of Nature), in: Stułkowski Sz. (ed.), "Otoczmy troską życie”. Kościół niosący Ewangelię Nadziei. Program duszpasterski Kościoła w Polsce na lata 2006-2010. Rok 2008/2009" "'Let us care for life. The Church Carrying the Gospel of Hope. Pastoral program of the Church in Poland for the years 2006-2010. 2008/2009”), Wydawnictwo Świętego Wojciecha, Poznań, 340-346.

Francis, 2015, Encyclical letter Laudato si', (Rome, 24.05.2015) <w2.vatican.va/content/francesco/en/ encyclicals/documents/papa-francesco_20150524_ enciclica-laudato-si.html>, accessed: 4.12.2019.

Jaromi S., 2007, Chrześcijanin a ekologia, in: Schulz A. (ed.), “Służyć Królestwu Bożemu w świecie, III Kongres Ogólnopolski Ruchów i Stowarzyszeń Katolickich" ("To serve the Kingdom of God in 
the World, 3rd National Congress of Catholic Movements and Associations"), ARWIL, Warsaw, 107-121.

Jaromi S., 2010a, Idea ogrodu św. Franciszka jako przykład chrześcijańskiej troski o bioróżnorodność (The idea of St. Francis' Garden of as an Example of Christian Concern for Biodiversity), in: Brusiło J. (ed.), Ogród Pana, XVIII Seminarium Sacrum $i$ przyroda (Lord's Garden, 18th Seminary Sacrum and Nature), Uniwersytet Papieski Jana Pawła II, Krakow, 83-94.

Jaromi S., 2010b, Eko-book o Eko-Bogu (Eco-book on Eco-God), Wydawnictwo "Salwator" Krakow. (Jaromi 2010b)

Jaromi S., 2011, Ruchy i stowarzyszenia w Kościele w stużbie ekologii (Movements and Associations in the Church in the Service of Ecology), Paedagogia Christiana, Vol. 28, No. 2, 195-210.

Jaromi S., 2014, Fundamenty polskiego domu, czyli Kościót $i$ ekologia (The Foundations of the Polish Home, or the Church and Ecology), in: Kassenberg A. (ed.), "Przez ekologię do wolności. Ruch ekologiczny a 25 lat przemian - refleksje na 25-lecie odzyskania suwerenności Polski" ("Through Ecology to Freedom. The Ecological Movement and 25 Years of Transformations Reflections on the 25th Anniversary of Poland's Regaining Sovereignty), Ministerstwo Środowiska, Warsaw, 28-32.

John Paul, 1991, Encyclical Centesimus annus (Vatican, 1.05.1991); document available online: <w2.vatican.va/content/john-paul-ii/en/ encyclicals/documents/hf_jp-ii_enc_01051991_ centesimus-annus.html $>$, accessed: 19.06.2019.

Poznański J., Jaromi S. (eds), 2016, Kościót i nauka w obliczu ekologicznych wyzwań. Źródta, inspiracje $i$ konteksty encykliki Laudato si' (Church and Science in the Face of Ecological Challenges. Sources, Inspirations and Contexts of the Encyclical Laudato si'), Wydawnictwo WAM, Krakow.

REFA Archive.

Statut REFA, Archiwum REFA (REFA Statute, REFA Archives).

Tomasz z Celano, 1981, Życiorys drugi Świętego Franciszka z Asyżu (Second Biography of St. Francis of Assisi), Chapter CXXIV, in: Kafel S. (ed.), "Wczesne źródta franciszkańskie" ("Early Franciscan Sources"), Vol. 1, Akademia Teologii Katolickiej, Warsaw.
(Web-01) Ogólnopolska Rada Ruchów Katolickich, Serwis Ruchów Katolickich (Polish Council of Catholic Movements. Catholic Movements Website), <www.orrk.pl>, accessed: 19.06.2019.

(Web-02) Zielony Zeszyt REFA, 2005, special edition; <www.swietostworzenia.pl/images/zielony-zeszyt/ zz2005_chrzescijanin.zip $>$, accessed: 19.06.2019. (Web-03) Święto Stworzenia. Portal ekologów chrześcijańskich (Festival of Creation. Portal of Christian Ecologists), <swietostworzenia.pl>, accessed: 19.06.2019.

(Web-04) Profil facebook Encyklika ekologiczna Laudato si' (Facebook profile Ecological Encyclical Laudato si') <www.facebook.com/ EncyklikaLaudatosi>, accessed: 19.06.2019.

(Web-05) Profil facebook Święto Stworzenia (Facebook profile Festival of Creation), <www. facebook.com/SwietoStworzenia/>, accessed: 19.06.2019.

(Web-06) Szkoła Liderów Ekologii Integralnej (The School of Integral Ecology Leaders and Other Initiatives), <https://swietostworzenia.pl/szkolaliderow/>, accessed: 19.06.2019.

(Web-07) List ekologów chrześcijan do uczestników COP24 (Letter from Christian Ecologists to COP24 Participants), <https://swietostworzenia. pl/2-aktualne/805-list-ekologow-chrzescijan-douczestnikow-cop24>, accessed: 19.06.2019.

(Web-08) Jedyna stata jest zmiana. Jak stawać sie liderem? (The Only Constant is Change. How to Become a Leader?), <https://www. swietostworzenia.pl/2-aktualne/783-jedyna-stalajest-zmiana-jak-stawac-sie-liderem>, accessed: 19.06.2019.

(Web-09) Uważność jako postawa serca (Mindfulness as an attitude of the heart), <https://www. swietostworzenia.pl/2-aktualne/795-uwaznoscjako-postawa-serca>, accessed: 19.06.2019.

(Web-10) Apel chrześcijan i ludzi dobrej woli o poszanowanie stworzenia (Appeal of Christians and the People of Good Will for Respect of Creation), <https://www.swietostworzenia.pl/2aktualne/833-apel-chrzescijan-i-ludzi-dobrejwoli-o-poszanowanie-stworzenia>, accessed: 19.06.2019.

(Web-11) Czas dla Stworzenia - Season of Creation, $<$ https://swietostworzenia.pl/nasze-dzialania /53-czas-dla-stworzenia-season-of-creation>, accessed: 19.06.2019. 
(Web-12) Święto Stworzenia w Polsce 2017 podsumowanie (Festival of Creation in Poland 2017), <https://www.swietostworzenia.pl/ nasze-dzialania/53-czas-dla-stworzeniaseason-of-creation/739-swieto-stworzenia-wpolsce-2017-podsumowanie>, accessed: 19.06.2019. (Web-13) Eco-Village Laudato si' na ŚDM 2016 (Eco-Village Laudato si' for the World Youth Day 2016), <https://swietostworzenia.pl/naszedzialania/650-eco-village-laudato-si-na-sdm>, accessed: 19.06.2019.

(Web-14) Szef REFA wyróżniony tytułem Człowieka Roku Polskiej Ekologii (Head of REFA awarded the title of Man of the Year in Polish Ecology, <https:// swietostworzenia.pl/o-nas/nasze-nagrody-iwyroznienia/688-szef-refa-wyrozniony-tytulemczlowieka-roku-polskiej-ekologii>, accessed: 19.06.2019.

(Web-15) Oswajamy przyrodę miasta i okolic (Becoming Familiar with the Nature of the City and the Surrounding Area), <https:// swietostworzenia.pl/nasze-dzialania/przyrodamiasta/697-o-projekcie>, accessed: 19.06.2019.

(Web-16) Franciszkańska książka o. Stanisława Jaromi (Franciscan Book Fr. Stanisław Jaromi), $<$ https://swietostworzenia.pl/2-aktualne/797franciszkanska-ksiazka-o-stanislawa-jaromi>, accessed: 19.06.2019.

\section{Być ekologiem wśród katolików... Szkoła liderów ekologii integralnej i inne inicjatywy Ruchu Ekologicznego Franciszka z Asyżu (REFA)}

\section{Streszczenie}

Niniejsze opracowanie przedstawia w bardzo skróconej formie bogatą działalność Ruchu Ekologicznego św. Franciszka z Asyżu (REFA), który powstał w środowisku polskich franciszkanów i od ponad 30 lat upowszechnia w Polsce potrzebę zaangażowania się chrześcijan w działania na rzecz ochrony środowiska. Motto REFA to "katolicy wśród ekologów, ekolodzy wśród katolików". W swej działalności REFA podjął wiele różnych prośrodowiskowych inicjatyw i zrealizował wiele ekologicznych projektów. W opracowaniu tym przedstawiono przynajmniej część z nich.

\section{Słowa kluczowe}

Ruch Ekologiczny św. Franciszka z Asyżu, REFA, chrześcijańska ekologia, ekologia integralna, kryzys ekologiczny

\section{Noty o Autorach}

EMILIA ŚLIMKO - magister psychologii, etnologii i antropologii kulturowej (UJ), członkini Zarządu Ruchu Ekologicznego św. Franciszka z Asyżu, specjalistka ds. edukacji ekologicznej, koordynatorka "Szkoły liderów ekologii integralnej”, redaktorka portalu www.swietostworzenia.pl.

0. Stanistaw Jaromi OFM Conv. - doktor filozofii, wieloletni delegat franciszkanów ds. sprawiedliwości, pokoju i ochrony stworzenia, przewodniczący Ruchu Ekologicznego św. Franciszka z Asyżu (REFA) i szef portalu www.swietostworzenia.pl. Od ponad 30 lat aktywnie angażuje się na rzecz rozwoju chrześcijańskiej ekologii.

\section{Authors' note}

EMILIA ŚLIMKO - holder of MA degree in psychology, ethnology and cultural anthropology (Jagiellonian University), member of the Management Board of the St. Francis of Assisi Environmental Movement (REFA), specialist in ecological education, coordinator of the "School of integral ecology leaders", editor of the website www.swietostworzenie.pl.

O. StanisŁaW Jarom OFM Conv. - holder of PhD in philosophy, long-time Franciscan delegate for justice, peace and protection of creation, chairman of St. Francis of Assisi Environmental Movement (REFA) and head of the website www.swietostworzenie.pl. Over the last 30 years, he has been actively involved in the development of Christian ecology. 